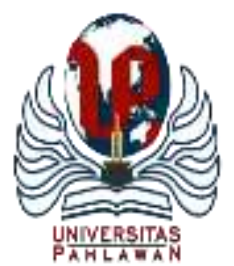

\title{
JURNALBASICEDU
}

Volume 6 Nomor 1 Tahun 2022 Halaman 749 - 758

Research \& Learningin Elementary Education

https://jbasic.org/index.php/basicedu

\section{Desain Pembelajaran Kooperatif dalam E-Learning pada Program Studi Pendidikan Guru Sekolah Dasar}

\author{
Muhammad Lukman Haris Firmansah \\ Pendidikan Guru Sekolah Dasar Universitas PGRI Ronggolawe Tuban, Indonesia \\ E-mail: Firmantp2013@gmail.com
}

\begin{abstract}
Abstrak
Pembelajaran online di era industri 4.0 semakin berkembang pesat. Namun pembelajaran tersebut belum dapat memfasilitasi siswa dalam aktivitas diskusi. Beberapa model pembelajaran belum dapat di implemetasikan. Pembelajaran online masih berpusat pada tatap muka, untuk itu diperlukan sebuah model pembelajaran pada pembelajara online. Untuk itu penelitian ini dilakukan untuk memastikan bahwa dengan diterapkannya pembelajaran online model kooperatif dapat di implementasikan dengan bantuan dan pengunaan fasilitas yang merupakan kombinasi dari aplikasi google classroom, google meet, blogger dan link grup whatsapp. Tujuan penelitian ini agar mahasiswa dapat berperan aktif dalam berdiskusi. Dengan adanya kombinasi diharapkan dapat tercipta pembelajran koperatif secara online diharapkan dapat mengaktifkan peserta didik serta dapat mengaktifkan diskusi kelompok. Melalui kegiatan diskusi peserta didik dapat berperan serta dan berpartisipasi baik segi pemikiran dan empati antar sesama anggota kelompok. Metode penelitian yag digunakan adalah penelitian pengembangan dengan type utility atau pemanfaatan sebuah aplikasi untuk pembelajaran. Penelitian ini dilakukan dengan jumlah subjek penelitian berjumlah 76 mahasiswa terdiri dari 3 kelas yakni kelas 2018 A, 2018 B dan 2018 C. Adapun hasil penelitian menunjukkan bahwa rata-rata $90 \%$ mahasiswa berpartisipasi dalam diskusi, $100 \%$ ikut menyimpulkan melalui kegiatan diskusi, $87 \%$ mengatakan bahwa diskusi melalui efektif, dan $90 \%$ dari bukti screenshot teleconference menunjukkan mahasiswa aktif terlibat dalam diskusi. Hal tersebut membuktikan bahwa dengan adanya kolaborasi fitur whatsapp dapat menunjang mahasiswa untuk berdiskusi.
\end{abstract}

Kata kunci: Pembelajaran kooperatif, e-learning, Pendidikan Guru Sekolah Dasar

\begin{abstract}
Online learning in the industrial era 4.0 is growing rapidly. However, this learning has not been able to facilitate students in discussion activities. Some learning models cannot be implemented yet. Online learning is still centered on face-to-face, for that we need a learning model for online learning. For this reason, this research was conducted to ensure that with the implementation of cooperative online learning models can be implemented with the help and use of facilities which are a combination of the google classroom application, google meet, blogger and whatsapp group link. The purpose of this study is that students can play an active role in discussions. With the combination, it is hoped that online cooperative learning can be created which is expected to activate students and can activate group discussions. Through discussion activities, students can participate and participate both in terms of thinking and empathy among fellow group members. The research method used is development research with utility type or the use of an application for learning. This research was conducted with the number of research subjects totaling 76 students consisting of 3 classes namely class 2018 A, 2018 B and 2018 C. The results showed that on average $90 \%$ of students participated in discussions, $100 \%$ participated in concluding through discussion activities, $87 \%$ said that the discussion through was effective, and $90 \%$ of the teleconference screenshot evidence showed students were actively involved in the discussion. This proves that with the collaboration of the Whatsapp feature, it can support students to discuss.
\end{abstract}

Keywords: Cooperative learning, e-learning, primary teacher Education

Copyright (c) 2022 Muhammad Lukman Haris Firmansah

$\triangle$ Corresponding author :

Email : Firmantp2013@gmail.com

DOI : https://doi.org/10.31004/basicedu.v6i1.2052

ISSN 2580-3735 (Media Cetak)

ISSN 2580-1147 (Media Online)

Jurnal Basicedu Vol 6 No 1 Tahun 2022 


\section{PENDAHULUAN}

Pada saat pandemi Covid 19 perguruan tinggi memberlakukan sistem pembelajaran secara online. Perubahan sistem pembelajaran dari pembelajaran tradisional ke sistem pembelajaran online mendorong pembelajar untuk mempelajari, memiliki dan menguasai ICT Latip, (2020);Anshori, (2018). Bagi mereka yang belum mengetahui tentang e-learning tentunya ini merupakan hal yang baru, dan harus dipelajari. Apabila diteliti terjadi perubahan yang sangat singnifikan, baik dari penggunaan fasilitas dan aktivitas belajar siswa. Pembelajaran online menitik beratkan pada kemandirian peserta didik dalam hal mencari informasi, memperoleh informasi dan sintesis pengetahuan ke pengetahuan baru. Tentunya banyak aktivitas yang tidak dapat dilakukan ketika diberlakukan Sistem pembelajaran online seperti diskusi tatap muka, simulasi, dan lainnya.

Pembelajaran online mendorong para pendidik melakukan inovasi pembelajaran, menggunakan softwere dan hadrwere sebagai sumber belajar dan media pembelajaran untuk mencapai tujuan pembelajaran Trisiana, (2020);Subakti et al., (2021). Dilihat dari fungsi dan tujuan penggunaan softwere sebagai sumber belajar dan media pembelajaran dalam Sistem pembelajaran e-learning ada beberapa aktivitas yang terlihat belum dioptimalkan yakni diskusi tatap muka. Diskusi dengan Sistem pembelajaran menggunakan aplikasi google classroom/moodle masih terbatas pada diskusi tertulis. Sistem pembelajaran belum mendorong pada diskusi tatap muka sehingga diperlukan aplikasi atau softwere lain untuk mendorong hal tersebut yakni whatsapp grup. Penggunaan whatsapp grup dengan link memungkinkan peserta bertemu langsung dengan anggota grup secara tertulis dan tatap muka. Peserta didik dimasukkan ke dalam grup melalui link-link yang sudah dibuat berdasarkan pembagian kelompok. Selanjutnya peserta didik mendiskusikan topik materi yang diberikan oleh pendidik (Alkindi, SD, \& Baru, 2021).

Pada era industri 4.0 diskusi dapat meggunakan beragam aplikasi. Pada penelitia ini menggunakan aplikasi whatsapp yang berkolaborasi dengan google classroom. Adapun kelebihan dari whatsapp massegger yakni mahasiswa dapat berdisksi secara sychronos atau tatap muka dan hasil dari diskusi disampaikan mengguakan aplikasi google meet. Kolaborasi 3 aplikasi yakni whatsapp, google meet, dan google classroom untuk mendukung pembelajaran kolaboratif secara online (Nana \& Surahman, 2019).

Diskusi grup merupakan aktivitas yang penting dalam pembelajaran sebab melalui diskusi anak dapat berbagi informasi, serta menggabungkan beberapa pengetahuan dari anggota grup kemudian menyimpulkannya. Diskusi sendiri diartikan sebagai "suatu cara penyajian/penyampaian bahan pelajaran, dimana dosen memberikan kesempatan para peserta didik untuk mengadakan pembicaraan ilmiah guna mengumpulkan pendapat, membuat kesimpulan atau menyusun berbagai alternatif pemecahan dalam suatu masalah". Penggunaan metode diskusi sendiri sangat penting tergantung pada model pembelajaran tersebut. Ada beberapa macam yang dapat mendorong peserta didik untuk berdiskusi yakni model pembelajaran kooperatif. Pembelajaran kooperatif merupakan pembelajaran yang dibentuk dalam suatu kelompok kecil dimana siswa bekerja sama dan mengoptimalkan keterlibatan diriya dan anggota kelompoknya dalam belajar Rosita \& Leonard, (2015); Fiteriani \& BAHARUDIN, (2017)

Menurut Hayati, (2017) menjelaskan pembelajaran kooperatif dilakukan dengan membentuk kelompok kecil yang anggotanya heterogen untuk bekerja sebagai sebuah tim dalam menyelesaikan masalah. Selanjutnya menurut AFANDI, (2021) beberapa ketentuan dalam pembelajaran kooperatif yaitu : 1) peserta didik menanggung resiko baik buruknya hasil yang diperoleh kelompoknya dalam melaksanakan diskusi,2) setiap peserta didik memiliki tanggungjawab terhadap peserta didik lain dalam kelompoknya, disamping tanggugjawab terhadap dirinya sendiri dalam mempelajari materi yang dihadapinya, 3) memiliki tujuan yang sama, 4) membagi tugas dan tanggung jawab yang sama besarnya di antara anggota kelompok, 5) para peserta didik diberikan evaluasi atau penghargaan yang berpengaruh pada seluruh kelompok, 6) para peserta didik berbagi kepemimpinan sementara mereka memperoleh keterampilan bekerjasama selama belajar, 7) para 
peserta didik dimintai pertanggungjawabannya secara individual tentang materi yang dipelajarinya dalam kelompoknya. Adapun manfaat dari pembelajaran kooperatif yakni 1)Meningkatkan hasil belajar pembelajar, 2)Meningkatkan hubungan antar kelompok, belajar kooperatif memberi kesempatan kepada setiap pembelajar untuk berinteraksi dan beradaptasi dengan teman satu tim untuk mencerna materi pelajaran, 3)Meningkatkan rasa percaya diri dan motivasi belajar, belajar kooperatif dapat membina sifat kebersamaan, peduli satu sama lain dan tenggang rasa, serta mempunyai rasa andil terhadap keberhasilan tim, 4)Menumbuhkan realisasi kebutuhan pembelajar untuk belajar berpikir, belajar kooperatif dapat diterapkan untuk berbagai materi ajar, seperti pemahaman yang rumit, pelaksanaan kajian proyek, dan latihan memecahkan masalah, 5)Memadukan dan menerapkan pengetahuan dan keterampilan, 6) Meningkatkan perilaku dan kehadiran di kelas, 7)Relatif murah karena tidak memerlukan biaya khusus untuk menerapkannya. Veldman, Doolaard, Bosker, \& Snijders, (2020);Abramczyk \& Jurkowski, (2020); Van Ryzin, Roseth, \& Biglan, (2020).

Model kooperatif dengan bantuan whatsapp grup yakni peserta didik dimasukkan dalam grup diskusi yang beranggotakan 2 sd 3 orang, kemudian mempelajari materi bersama-sama pendidik, selanjutnya bentuk dari penguasaan materi tersebut peserta didik diarahkan untuk berdiskusi dalam grup mengenai tugas yang diberikan oleh pendidik. Gambaran tugas yang diberikan pendidik merupakan kesimpulan serta terapan dari materi yang diberikan. Melalui aktivitas belajar tersebut peserta didik diharapkan dapat bekerjasama dalam menguasai materi dari tugas yang diberikan. Hasil dari diskusi disampaikan secara langsung secara synchronous oleh anggota kelompok yang dipilih secara acak dari jumlah kelompok yang dibentuk. Selanjutnya, peserta didik mengirim screenshot dari hasil diskusi, nama kelompok, dan anggota kelompok ke email setelah presentasi.

Penggunaan sistem pembelajaran online type whatsapp grup diharapkan peserta didik dapat melakukan aktivitas diskusi tanpa terbatasi ruang dan waktu. Adapun alasan pemilihan penggunaan sistem pembelajaran menggunakan whatsapp grup yakni 1) tersedianya fasilitas teleconference atau video call, 2) Mayoritas mahasiswa menggunakan softwere tersebut, 3) Tersedianya fasilitas grup dalam softwere tersebut. Hal ini membuktikan bahwa peserta didik dapat beraktivitas social secara synchronous.

Sistem pembelajaran online merupakan iinteraksi antar komponen system yakni peserta didik, pendidik, dan sumber belajar dalam situasi belajar secara online baik synchronous maupun asynchronous. Penggunaan system pembelajaran mengatasi jarak antar pendidik dengan peserta didik dan menjadikan lokasi sebagai kondisi lingkungan dimana mereka siap untuk berinteraksi, mencari dan memperoleh ilmu. Keterlibatan peserta didik seringkali menjadi kendala dalam pembelajaran online dengan berbagai macam alasan, padahal pada situasi apapun siswa dapat mengikuti dan berpatisipasi secara langsung. Dari berbagai metode online yang digunakan, penggunaan aplikasi google classroom dengan bantuan whatsapp merupakan metode yang dapat mengaktifkan peserta didik dalam berdiskusi dalam pembelajaran daring.

Google Classroom adalah layanan web gratis, yang dikembangkan oleh google untuk sekolah, yang bertujuan untuk menyederhanakan membuat, mendistribusikan, dan menilai tugas tanpa harus bertatap muka. Tujuan utama Google Kelas adalah untuk merampingkan proses berbagi file antara guru dan siswa. Selain itu, fitur youtube dapat digunakan untuk menghubungkan google classroom dengan aplikasi lain seperti google meet, blogger, dan grup whatsapp melalui fitur ungdapgah link.

Adapun keunikan penelitian yakni memanfaatkan whatsapp sebagai sarana diskusi yang merupakan bagian dari proses belajar yang kemudian dikomunikasikan dengan menggukan aplikasi google meet. Pada umumnya pembelajaran hanya dilakukan dengan tatap muka secara online maupun online. Perbedaan ini dengan penelitian kooperatif lainnya yakni pendidik dapat masuk ke grup whatsapp mahasiswa secara face to face dan memantau disksi yang sedag dilakukan, sehingga dapat memiimalisir gap pembelajaran online maupun offline dalam hal pembelajaran kooperatif. Adapun penelitian ini dilakukan untuk memfasilitasi siswa berdisksi dalam grup pada saat pademi yang mendorong pembelajaran secara online. 


\section{METODE PENELITIAN}

Jenis penelitian yang digunakan pada penelitian ini adalah penelitian pengembangan, yakni mengembangkan system pembelajaran daring dengan menggunakan google classroom dan berbantuan whatsapp dengan menggunakan undang via tautan. Adapun model pengembangan yang digunakan dalam pada penelitian ini yakni model ADDIE (Tegeh, Jampel, \& Pudjawan, 2015). Tahapan model ADDIE meliputi analisis, desain, development, implementasi dan evaluasi. Adapun desainnya sebagai berikut

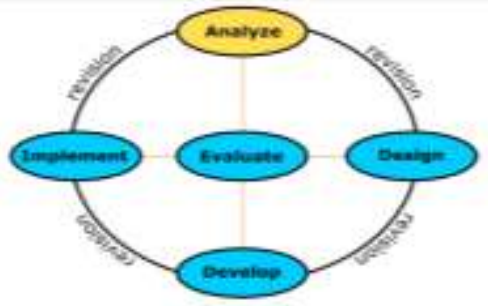

\section{Gambar 1. Model pengembangan ADDIE (Pribadi, 2016)}

Tahap analisis meliputi performance analisis dan analisis kebutuhan. Pada tahap performance analisis merupakan tahap menganalisa kinerja apa yang ada dalam pembelajaran online yakni belum dapat mengoptimalkan aktivitas kerjasama atau diskusi. Tahap analisis kebutuhan untuk menentukan kemampuankemampuan atau kompetensi yang perlu dipelajari yakni kompetensi bekerjasama. Analisis kinerja yang dijadikan pedoman yakni kinerja diskusi secara online

Tahap desain merupakan tahap perencanaan dan pemilihan media yang meliputi bagaimana pembelajaran direncanakan, pembelajaran direncanakan dengan cara menyiapkan materi, membagi kelompok beranggotakan 4 sampai dengan 6 peserta didik dilanjutkan dengan memilih media apa yang dapat memfasilitasi agar anak dapat berdiskusi kelompok kemudian mempresentasikkannya yakni whatsapp grup, google classroom dan google meet untuk mpresentasikan hasil diskusinya. Whatsapp digunakan untuk berdikusi tatap muka dengan angota kelompok sedangkan google meet digunakan untuk mempresentasikan hasil diskusinya. Penggunaan fasilitas screenshot pada whatsapp grup digunakan sebagai penilaian bahwa anggota kelompok berpartisipasi aktif dalam kelompok.

Tahap selanjutnya adalah tahap pengembangan digunakan untuk meninjau kembali atau merevisi media pembelajaran sudah dapat digunakan untuk mencapai tujuan pembelajaran atau tidak. Adapun identifikasi tujuan sudah sesuai dengan desain yang digunakan untuk mencapai tujuan tersebut. Pada tahap ini juga dilakukan evaluasi pemilihan softwere yang dapat mendukung pembelajaran daring dengan mengutamakan aktivitas diskusi.

Tahap implementasi dimana proses pembelajaran diterapkan untuk meninjau pelaksanaan dan kendala yang dihadapi. Pada kenyataannya anak tercatat mahir menggunakan whatsapp untuk berdiskusi dan teleconferen menggunakannya. Melihat dari screenshot peserta didik didalam grup diskusi terlihat aktif dan proses penyimpulan berdasarkan keputusan bersama.

Tahap evaluasi digunakan untuk mengidentifikasi kelemahan produk mulai tahapa analisis, design, development dan implementasi. Tahap ini juga digunakan untuk melakukan perbaikan-perbaikan dalam melaksanakan pembelajaran kooperatif pada pembelajaran online. Evaluasi meliputi evaluasi perancangan dan evaluasi proses.

\section{HASIL DAN PEMBAHASAN}

Penyebaran Covid-19 yang diIndonesia mengakibatkan perubahan-perubahan dalam kehidupan seharihari hingga berdampak pada pembelajaran. sebuah instansi pendidikan harus memikirkan dan berdiskusi dan membuat kebijakan baru terkait pelaksanaan kegiatan pembelajaran yang pelaksanaannya awalnya secara 
klasikal tatap muka berganti menjadi kegiatan pembelajaran dirumah saja. Hal-hal yang baru yang muncul menggantikan kebiasaan lama seperti pembelajaran dengan tatap muka didalam kelas berubah secara keseluruhan menjadi perkuliahan daring dan bahkan ujian online.

Jenis penelitian pada ini yakni pengembangan by utility atau pemanfaatan dengan menguji cobakan sebuah desain pembelajaran kooperatif yang diujicobakan pada 3 kelas. Data diperoleh berupa deskriptif yang disajikan dalam bentuk diagram sedangkan data kuantitatif digunakan untuk memberikan nilai pembelajaran. Alasan pemilihan data deskriptif sebab desain pembelajaran hanya dilakukan pada 1 pertemuan dalam serangkaian pembelajaran. Pemilihan aplikasi didasarkan pada interface yakni beberapa aplikasi dapat teritegrasi dalam 1 halaman melalu link yakni google classroom, google meet dan whatsapp grup.

Subjek penelitan yakni mahasiswa angkatan 2018 kelas A, 2018 kelas B dan 2018 kelas C dengan jumlah total mahasiswa 76 mahasiswa. Instruksi pembelajaran yakni 1) bagilah kelompok beranggotakan 4 sampai dengan 6 mahasiswa kemudian, 2) pelajari materi kuliah yang telah disediakan, 3) dari jumlah kelompok kemudian dipilih kelompok yang menjadi kelompok penyaji, 4) mahasiswa mengerjakan contoh soal yang ada dalam materi, 5) dosen melakukan tanya jawab berkaitan contoh soal, 6) mahasiswa menyampaikan dan menjawab pertanyaan dosen berdasarkan hasil diskusi. 7) screenshot hasil diskusi di whatsapp dan telekonferen.

Hasil diskusi di kelompok whatsapp menunjukkan bahwa 91\% mahasiswa kelas A berpartisipasi aktif dalam diskusi, satu sama lainnya saling mengomentari contoh soal yang disediakan. $100 \%$ menunjukkan bahwa kesimpulan yang dibuat oleh grup berdasarkan hasil diskusi. $87 \%$ mengatakan bahwa diskusi lebih efektif sambil melakukan obrolan ringan. Berdasarkan hasil analisis dokumen yang dikirim berupa screenshoot hasil diskusi dan telekonferen diperoleh $91 \%$ mahasiswa terlibat dalam diskusi.

Sedangkan hasil diskusi mahasiswa kelas B menunjukkan bahwa $88 \%$ ikut berpatisipasi aktif dalam diskusi. 100\% kesimpulan diskusi diputuskan secara bersama-sama. $84 \%$ mengatakan diskusi melalui whatsapp dalam kategori efektif. Dan $88 \%$ mahasiswa terlibat dalam diskusi.

Hasil diskusi yang dikelas $\mathrm{C}$ yang berjumlah 28 mahasiswa menunjukkan $89 \%$ ikut berpatisipasi dalam kegiatan diskusi. 100 mahasiswa menyimpulkan melalui dikusi. 89\% menunjukkan bahwa diskusi melalui whatsapp efektif. Dan persentase mahasiswa yang terlibat dalam diskusi $89 \%$. Adapun diagramnya disajikan sebagai berikut.

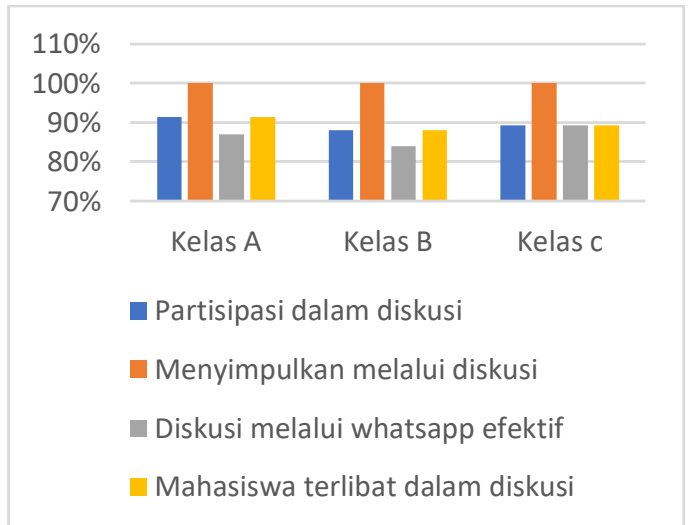

\section{Gambar 2 Diagram Batang partisipasi dalam diskusi}

Dari diagram diatas menunjukkan bahwa dengan menggunakan whatsapp grup dapat mahasiswa dalam berpartisipasi dalam diskusi. Diskusi dilakukan secara tertulis maupun tatap muka. Mahasiswa cenderung melakukan diskusi tertulis untuk membahas topik-topik. Sedangkan diskusi tatap muka dilakukan untuk membahas topik yang disepakati untuk dijawab dan disajikan atau dipresentasikan. Adapun hasilnya yakni keterlibatan diskusi dalam kategori baik, dan penyajian hasil diskusi dengan kriteria sangat baik. Hasil tersebut disajika dalam diagram berikut. 


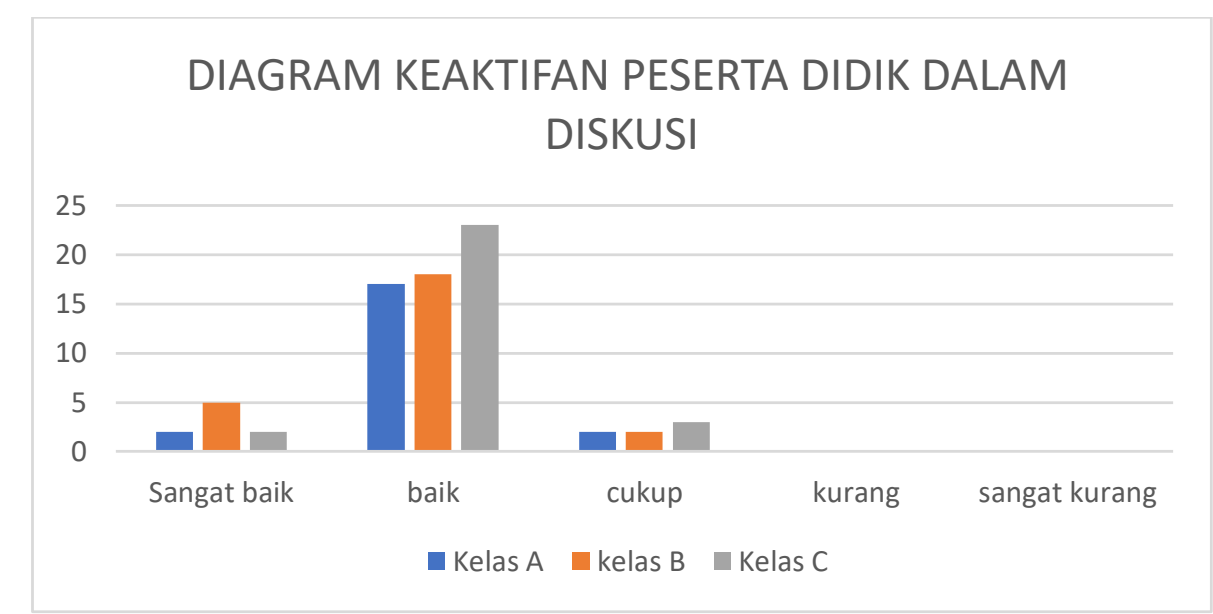

Gambar 3 Diagram Batang Kategori keterlibatan dalam diskusi

Pengukuran efektitifas penggunaan whatsapp dilakukan dengan menggunakan angket dari jumlah peserta didik. Berdasarkan hasil angket menunjukkan bahwa diskusi melalui whatsapp efektif dalam arti mudah digunakan dan membantu dalam proses pembelajaran. Selain itu aplikasi whatsapp merupakan aplikasi keseharian yang biasa digunakan oleh peserta didik Jadi mereka terbisa meggunakannya. Hal tersebut dapat dilihat dari diagram penggunaan teknologi.

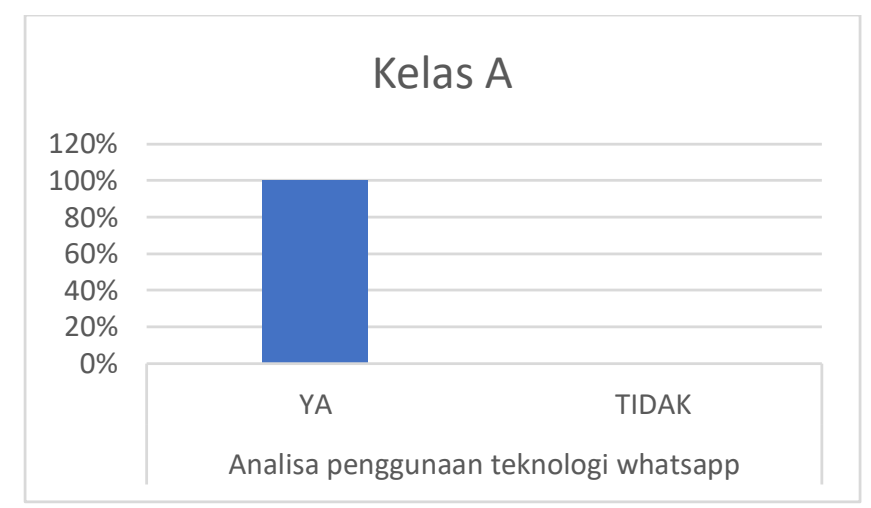

\section{Gambar 4 Diagram Batang penggunaan teknologi kelas A}

Diagram diatas menunjukkan $100 \%$ dari jumlah 23 mahasiswa menggunakan whatsapp. Dan membuat grup whatsapp berdasarkan kelompok dan melakukan diskusi. Hasil diatas merupakan hasil pada kelas A dari analisa jumlah anggota pada grup whatsapp. selanjutnya pada kelas B sebagai berikut

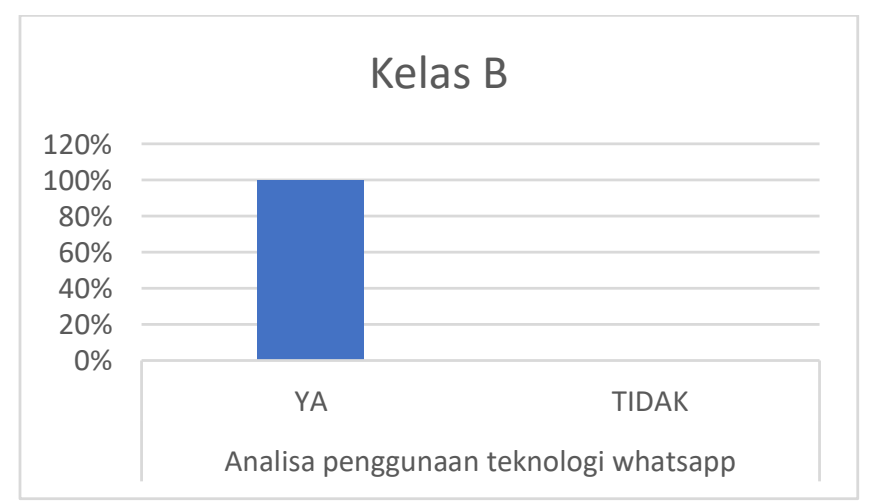

Gambar 5 Diagram Batang penggunaan teknologi kelas B 
Diagram diatas menunjukkan $100 \%$ dari jumlah 25 mahasiswa menggunakan whatsapp. Dan membuat grup whatsapp berdasarkan kelompok dan melakukan diskusi. Hasil diatas merupakan hasil pada kelas B dari analisa jumlah anggota pada grup whatsapp. selanjutnya pada kelas $\mathrm{C}$ sebagai berikut:

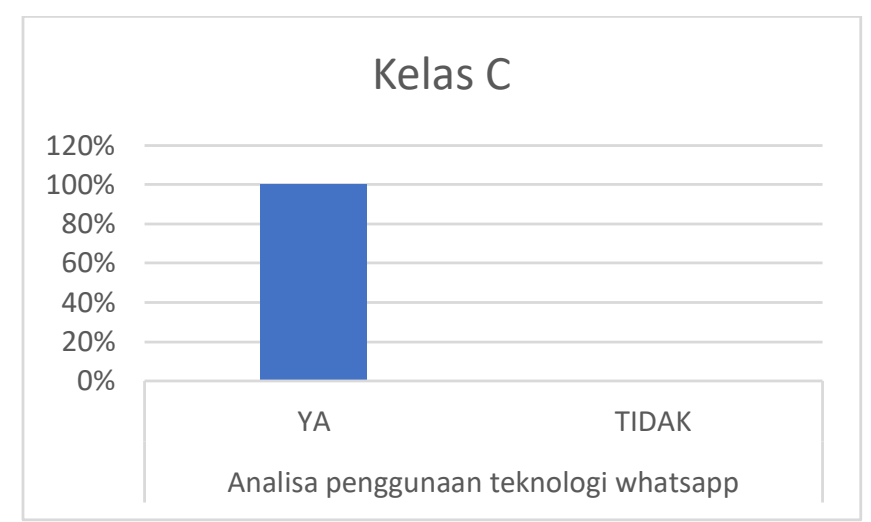

Gambar 6 Diagram Batang penggunaan teknologi kelas C

Diagram diatas menunjukkan $100 \%$ dari jumlah 28 mahasiswa menggunakan whatsapp. Dan membuat grup whatsapp berdasarkan kelompok dan melakukan diskusi.` Hasil diatas merupakan hasil pada kelas B dari analisa jumlah anggota pada grup whatsapp.

Dari jumlah data yang ada pada grup whatsapps diambil dari jumlah peserta yang ada di google classroom 76 peserta didik. Jadi desain ini dimulai dari penggunaan google classroom kemudian menggunakan google meet untuk dimanfaatkan untuk membagi kelompok dan juga memberikan penjelasan kemudian memanfaatkan aplikasi whatsapp grup digunakan sebagai sarana diskusi kemudian kembali menggunakan google meet untuk menyajikan hasil dari diskusi. Pola penggunaan tersebut mengikuti sintak pembelajaran kooperatif yakni 1) menyampaikan tujuan dan memotivasi pembelajar, 2) meyajikan informasi, sintak ke 1 dan ke 2 menggunakan aplikasi google meet. Selanjutnya 3) mengorganisasikan pembelajar ke dalam kelompok-kelompok belajar, dan 4) membimbing kelompok bekerja dan belajar, ini menggunakan whatsapp grup 5) evaluasi, 6) memberikan penghargaan. Hayati, (2017);Casey \& Quennerstedt, (2020)

Pola komunikasi dengan whatsapp dalam penyampaian pesan, baik dosen maupun mahasiswa berkomunikasi satu sama lain secara verbal dan nonverbal. Komunikasi verbal dilakukan dengan mengirimkan voice note atau rekaman suara dari komunikator kepada seluruh komunikan yang terlibat di dalam grup. Komunikasi verbal juga dilakukan melalui panggilan video yang dilakukan secara bergiliran dengan batasan 6 mahasiswa di setiap sesinya. Berbeda dengan komunikasi verbal, komunikasi nonverbal dimanifestasikan dalam bentuk tulisan, gambar, meme, sticker, dan emoticon seperti jempol, senyum, bahagia, simbol '100' dan simbol yang lainnya (Casey \& Quennerstedt, 2020);(Maulidina, 2021).

Menurut penelitian yang dilakukan (Pamungkas, Aini, Novianti, \& Sulisworo, 2020). Google Classroom adalah alat berbasis web gratis yang dikembangkan oleh Google. Saat itu diperkenalkan pada 12 Agustus di tahun 2014. Aplikasi ini digunakan oleh para guru dan siswa, untuk berbagi file di antara mereka. Di Google Classroom, guru dapat membuat tugas untuk siswa, dan juga dapat mengumpulkan tugas dari mereka. Baik guru dan siswa dapat bekerja tanpa menggunakan kertas dalam aplikasi ini. Berikut ini beberapa hal yang bisa dilakukan saat belajar secara daring (online) dengan Google Classroom:

a. Berbagi materi pelajaran/silabus

b. Memberikan/mengirimkan tugas

c. Mengadakan ujian/kuis Tanya jawab secara interaktif

d. Melihat tugas mendatang lewat Google Calendar 
Selain berbagai manfaat di atas, Google Classroom cocok dijadikan opsi untuk belajar online karena platform ini gratis, bisa dijangkau siapa saja yang menggunakan smartphone, dan relatif aman. Pada penelitian ini penggunaan google classroom sebagai rancangan pebelajaran sebelum dan sesudah pembelajaran dimulai.

Menurut penelitian yang dilakukan (Octafian, Putri, \& Andriani, 2021) Hasil tersebut memberikan gambaran bahwa $77 \%$ perserta menganggap sangat penting dan sisanya $23 \%$ menganggap penting dikarenakan peserta merasa bahwa pada era Covid-19 ini penggunaan aplikasi Google Meet adalah suatu sarana yang dapat membantu guru dalam proses pengajarannya selama kegiatan sekolah belajar di rumah. Pada penelitian ini google meet dikolaborasikan dengan aplikasi whatsapp guna mendukung pembelajaran yang aktif dan kooperatif.

Penggunaan pola atau sintak pembelajaran dan aplikasi terjadi keselarasan selanjutnya didesain menggunakan pola penelitian pengembangan yakni menggunakan desain ADDIE. Selajutnya pada penelitian ini diterapkan pada pembelajaran dengan menggunakan desain eksperimen tipe one shot case study dimana sekelompok subjek diberi perlakuan kemudian dilakukan pengamatan.

Pada desain ini peneliti menerima informasi mengenai akibat perlakuan. Perlakuan dapat diukur pada kemampuan berdiskusi di grup dengan indikator keterlibatan mahasiswa dalam berdiskusi dan kemampuan menyajikan hasil diskusi. Pengukuran dilakukan dengan skala likert dengan kriteria sangat baik, baik, cukup, kurang, sangat kurang.

Hasil tahap pengembangan aplikasi dengan type utility atau pemanfaatan aplikasi menunjukkan bahwa perpaduan aplikasi dapat dimanfaatkan untuk kebutuhan pembelajaran kooperatif, berdasarkan 5 tahap yakni analisis kebutuhan, design, development, implementasi dan evaluasi. Ditinjau analisis kebutuhan dan hasil menunjukkan pennggunaan aplikasi dapat memfasilitasi peserta didik dalam berdiskusi baik secara verbal, non verbal dan tatapmuka. Pada tahap desain peneliti mengatur penggunaan aplikasi agar sesuai sintak pembelajaran kooperatif. Sedangkan pada tahap development peneliti mengintegrasikan aplikasi dalam satu wadah atau interface menggunakan google classroom. Pada tahap implementasi menunjukkan bahwa peserta didik aktif terlibat dalam diskusi. Adapun langkah-langkah pada tahap implementasi yakni 1) pendidik menggunakan google classroom untuk menyampaikan tujuan pembelajaran dan membuat link grup whatsapp, 2) pendidik mengarahkan untuk menggunakan aplikasi google meet yang berisikan id dan password untuk pembelajaran tatap muka secara schronous, 3) pedidik menyampaikan penjelasan atau informasi sebagai apersepsi dan intruksi pembelajaran dengan membagi siswa menjadi beberapa kelompok serta mengarahkan siswa untuk masuk grup melalui link grup yang telah disediakan, 4) pendidik memantau diskusi secara verbal maupun non verbal serta mengarahkan peserta didik untuk menggunakan fitur video call, 5) pendidik memilih salah satu kelompok dari beberapa kelompok sebagai kelompok penyaji dan masuk dalam link grup google meet, 6) pendidik dan peserta didik bertemu secara synchronous dan memberi kesempatan kelompok penyaji untuk mempresetasikan, 7) pendidik memberikan umpan balik dan reinforcement dari materi tersebut, 8)pendidik menutup atau mengakhiri pembelajaran ,9) pendidik menilai keaktifan peserta didik dalam diskusi dan menilai subtansi dari diskusi yang dilakukan, 10) pendidik melakukan rekap penilaian pada pertemuan tersebut.

Tahap evaluasi pada tahap pengembangan desain produk dimulai tahap awal yakni analisis hingga implementasi. Pada tahap analisis menunjukkan dalam pembelajaran memerlukan sarana diskusi, dari beberapa aplikasi yang ada yang paling fleksibel dan banyak digunakan serta dapat dikonektivitas melalui link yakni whatsapp. Selain itu menyediakan fitur berupa grup dan tatap muka dalam jumlah terbatas. Selajutnya memilih sarana yang dapat mewadahi yakni google classroom agar terjadi koneksivitas. Kemudian dipilih aplikasi yang dapat digunakan untuk menyampaikan intruksi pembelajaran yakni google meet. Pemilihan google meet sebagai aplikasi tatap muka sebab dapat dikoneksikan dengan google classroom. Jadi learning management system atau LMS terletak pada google classroom untuk mengatur dan mengelola pembelajaran. Pada tahap design terjadi evaluasi yang awalnya hanya berisi silabus, rps dan ppt setiap pertemuan kemudian 
menjadi berisikan silabus, rps, rpp dan intruksi pembelajaran, hal ini bertujuan memberi pengantar pembelajaran dilakukan dengan cara pembelajaran akan dijalankan. Pada tahap pengembangan dilakukan penambahan pemberian link whatsapp grup pada google classroom. Pada tahap pelaksanaan terlihat peserta didik dapat mengikuti pembelajaran sesuai waktu yang ditentukan. Hal ini menunjukkan bahwa peserta didik sudah mahir menggunakan aplikasi tersebut.

Desain learning managemen system dijadikan pedoman untuk menyelenggarakan pembelajaran online atau e-learning. Learning management system pada penelitian ini mengikuti sintak pembelajaran kooperatif. Dimulai dengan menggunakan google classroom dilanjutkan dengan google meet dan materi ajar berbentuk ppt dan kemudian dilanjutkan dengan penggunaan whatsapp. Alasan pemilihan tahapan ini didasarkan pada pentingnya aktivitas diskusi dimasa pandemic. Pada umumnya e-learning menggunakan aplikasi moodle namun kelemahannya peserta didik tidak bisa dibagi kelompok, dan anggota kelompok tidak bisa bertatap muka secara synchronous antara satu sama lainnya.

\section{KESIMPULAN}

Adapun hasil penelitian menunjukkan bahwa rata-rata $90 \%$ mahasiswa berpartisipasi dalam diskusi, $100 \%$ ikut menyimpulkan melalui kegiatan diskusi, 87\% mengatakan bahwa diskusi melalui efektif, dan $90 \%$ dari bukti screenshot teleconference menunjukkan mahasiswa aktif terlibat dalam diskusi. Kegiatan diskusi melalui whatsapp terbukti dapat mengimplementasikan pembelajaran kooperatif dengan mode e-learning. Hal ini menunjukkan bahwa melalui fasilitas synchronous tidak menghalangi atau menghambat aktivitas diskusi. Mahasiswa tetap dapat berdiskusi dengan mempertimbangkan aspek kemandirian peserta didik.

\section{UCAPAN TERIMA KASIH}

Saya ucapkan terima kasih segenap civitas akademika yang memberi motivasi sehingga dapat terselesaikannya penelitian ini

\section{DAFTAR PUSTAKA}

Abramczyk, Anna, \& Jurkowski, Susanne. (2020). Cooperative Learning As An Evidence-Based Teaching Strategy: What Teachers Know, Believe, And How They Use It. Journal Of Education For Teaching, 46(3), 296-308.

Afandi, Mohammad Rifanto. (2021). Pengaruh Model Pembelajaran Kooperatif Tipe Stad (Student Teams Achievement Division) Terhadap Sikap Disiplin Dan Tanggung Jawab Peserta Didik Pada Mata Pelajaran Akidah Akhlak Kelas Viii Mtsn 7 Tulungagung.

Alkindi, Usama Luthfi, Sd, S. Pd, \& Baru, S. D. N. Kalasan. (2021). Pembelajaran Jarak Jauh Penuh Motivasi. Pembelajaran Di Masa Pandemi, Inovasi Tiada Henti (Kumpulan Best Practices Inovasi Pembelajaran), 43.

Anshori, Sodiq. (2018). Pemanfaatan Teknologi Informasi Dan Komunikasi Sebagai Media Pembelajaran. Civic-Culture: Jurnal Ilmu Pendidikan Pkn Dan Sosial Budaya, 2(1).

Casey, Ashley, \& Quennerstedt, Mikael. (2020). Cooperative Learning In Physical Education Encountering Dewey's Educational Theory. European Physical Education Review, 26(4), 1023-1037.

Fiteriani, Ida, \& Baharudin, Baharudin. (2017). Analisis Perbedaan Hasil Belajar Kognitif Menggunakan Metode Pembelajaran Kooperatif Yang Berkombinasipada Materi Ipa Di Min Bandar Lampung. Terampil: Jurnal Pendidikan Dan Pembelajaran Dasar, 4(2), 1-30.

Hayati, Sri. (2017). Belajar Dan Pembelajaran Berbasis Cooperative Learning. Magelang: Graha Cendekia, 
120.

Latip, Abdul. (2020). Peran Literasi Teknologi Informasi Dan Komunikasi Pada Pembelajaran Jarak Jauh Di Masa Pandemi Covid-19. Eduteach: Jurnal Edukasi Dan Teknologi Pembelajaran, 1(2), 108-116.

Maulidina, Dewi Hidayatul. (2021). Penggunaan Emoji Dalam Komunikasi Pembelajaran Daring Melalui Media Whatsapp (Studi Deskriptif Pada Mahasiswa Jurusan Bimbingan Penyuluhan Islam Institut Agama Islam Negeri Ponorogo Angkatan Tahun 2018). Iain Ponorogo.

Nana, Nana, \& Surahman, Endang. (2019). Pengembangan Inovasi Pembelajaran Digital Menggunakan Model Blended Poe2we Di Era Revolusi Industri 4.0. Prosiding Snfa (Seminar Nasional Fisika Dan Aplikasinya), 4, 82-90.

Octafian, D. Tri, Putri, Meidyan Permata, \& Andriani, Eni. (2021). Penggunaan Aplikasi Google Meet Sebagai Pendukung Kegiatan Mengajar Saat Menghadapi Pandemi Covid-19 Bagi Guru Sd N 149 Palembang. Jurnal Karya Abdi Masyarakat, 5(1), 154-160.

Pamungkas, Dwi, Aini, Noor, Novianti, Nita, \& Sulisworo, Dwi. (2020). Efektifitas Google Classroom Terhadap Keaktifan Mahasiswa Dalam Era Revolusi Industri 4.0. Theorema: The Journal Education Of Mathematics, 1(1), 44-53.

Pribadi, Benny A. (2016). Desain Dan Pengembangan Program Pelatihan Berbasis Kompetensi Implementasi Model Addie. Kencana.

Rosita, Ita, \& Leonard, Leonard. (2015). Meningkatkan Kerja Sama Siswa Melalui Pembelajaran Kooperatif Tipe Think Pair Share. Formatif: Jurnal Ilmiah Pendidikan Mipa, 3(1).

Subakti, Hani, Watulingas, Keren Hapkh, Haruna, Nana Harlina, Ritonga, Mesra Wati, Simarmata, Janner, Fauzi, Ahmad, Ardiana, Dewa Putu Yudhi, Rahmi, Siska Yulia, Chamidah, Dina, \& Saputro, Agung Nugroho Catur. (2021). Inovasi Pembelajaran. Yayasan Kita Menulis.

Tegeh, I. Made, Jampel, I. Nyoman, \& Pudjawan, Ketu. (2015). Pengembangan Buku Ajar Model Penelitian Pengembangan Dengan Model Addie. Seminar Nasional Riset Inovatif Iv, 208.

Trisiana, Anita. (2020). Penguatan Pembelajaran Pendidikan Kewarganegaraan Melalui Digitalisasi Media Pembelajaran. Jurnal Pendidikan Kewarganegaraan, 10(2), 31-41.

Van Ryzin, Mark J., Roseth, Cary J., \& Biglan, Anthony. (2020). Mediators Of Effects Of Cooperative Learning On Prosocial Behavior In Middle School. International Journal Of Applied Positive Psychology, 5(1), 37-52.

Veldman, M. A., Doolaard, S., Bosker, R. J., \& Snijders, T. A. B. (2020). Young Children Working Together. Cooperative Learning Effects On Group Work Of Children In Grade 1 Of Primary Education. Learning And Instruction, 67, 101308. 